\title{
Primary Osteoma of the Orbit with Atypical Facial Pain: Case Report and Literature Review
}

\author{
Atipik Fasial Ağrn ile Birlikte Primer Orbita Osteoması: Olgu Sunumu ve \\ Literatürün Gözden Geçrilmesi
}

\author{
Selim KAYACI ${ }^{1}$, Ayhan KANAT ${ }^{2}$, Hasan GUCER ${ }^{3}$, Hakan SECKİN $^{4}$ \\ ${ }_{1}^{1}$ Sar Hospital, Department of Neurosurgery, Rize, Turkey \\ ${ }^{2}$ Recep Tayyip Erdogan University, Faculty of Medicine, Department of Neurosurgery, Rize, Turkey \\ ${ }^{3}$ Recep Tayyip Erdogan University, Faculty of Medicine, Department of Pathology, Rize, Turkey \\ ${ }_{4}^{4}$ M.H. Diskapi Yildirim Beyazıt Education and Research Hospital, Department of Neurosurgery, Ankara, Turkey
}

Correspondence address: Selim KAYACI / E-mail: selim_kayaci@hotmail.com

\begin{abstract}
Osteoma is a benign, slowly growing tumor that mainly occurs in the bones and cavities of the middle third of the face, representing the most frequent benign tumor of the paranasal sinuses (3). It rarely originates primarily from the orbit. Most of these lesions develop in the fourth to fifth decades of life, and are more commonly encountered in males. In the English literature, there are so far three reported cases of primary osteoma of the orbit that originated from the sphenoid bone. Here we present another case of a primary osteoma of the orbit presenting with atypical facial pain and discuss the relevant literature.
\end{abstract}

KEYWORDS: Osteoma, Orbit, Primary, Sphenoid

öz

Osteoma yüzün orta bölümündeki kavite ve kemiklerden oluşan paranasal sinüslerin en sık görülen iyi huylu yavaş büyüyen bir tümörüdür (3). Nadir olarak orbitadan primer olarak köken alır. Bu lezyonlar çoğunlukla hayatın dört ve beşinci dekadlarında gelişir ve özellikle erkeklerde görülür. İngilizce literatürde günümüze kadar sfenoid kemikten orijin alan üç tane primer orbita osteoması bildirilmiştir. Biz atipik fasial ağrı ile birlikte olan diğer bir primer orbita osteomasını sunup literatür eşliğinde tartışıyoruz.

ANAHTAR SÖZCÜKLER: Osteoma, Orbita, Primer, Sfenoid

\section{INTRODUCTION}

Osteoma of the orbit is a benign lesion consisting primarily of mature cancellous bone (13). Most of these lesions develop in the fourth to fifth decades of life. There is evidence that osteoma is more commonly encountered in males. It has not been determined whether the osteomas are true neoplasms or are the result of an inflammatory reaction. Extension of osteomas into the orbit may cause severe morbidity, such as atrophy of the optic nerve, ophthalmoplegia, cephalgia, papillitis, and abscess. This report deals with a case of primary orbital osteoma that presented with severe cranial neuralgia, impaired eye mobility, and vision loss in the right eye.

\section{CASE REPORT}

An 80-year-old female patient was admitted with the complaints of vision loss and an intensive lancinating pain originating from her right eye and radiating hemicranially. Past medical history consisted of an admittance to a physician 20 years ago with a complaint of pain radiating to the right forehead and right eye. At that time, she was diagnosed with a right intraorbital tumor, and surgery was offered to the patient, but she had declined. The vision in her right eye started to decrease gradually and was lost two years ago. Additionally, an intense lancinating pain originating from her right eye started to radiate into the right hemicranium, all the way to her neck.

The neurological examination revealed exophthalmus, proptosis, and restricted eye movements in all directions, as well as papilledema in the right eye. The direct pupillary reflex was negative but the indirect pupillary reflex was positive.

Cranial and orbital computerized tomographic (CT) scans showed a right hyperdense intraorbital mass lesion measuring $2.5 \times 4.5 \times 2 \mathrm{~cm}$. The lesion was arising from the posterolateral wall of the lesser wing of the sphenoid bone with a lobulated contour. It caused bony expansion in the sphenoid bone, and caused indentation on the lateral rectus muscle and optic nerve displacing the globe anteriorly (Figures $1 \mathrm{~A}-\mathrm{C}, 2$ ).

The patient refused surgical removal of the tumor again and a biopsy was planned to exclude a possible malignant degeneration of an existing lesion, with a suspicion of a rapid increase of the tumor size, according to the history 


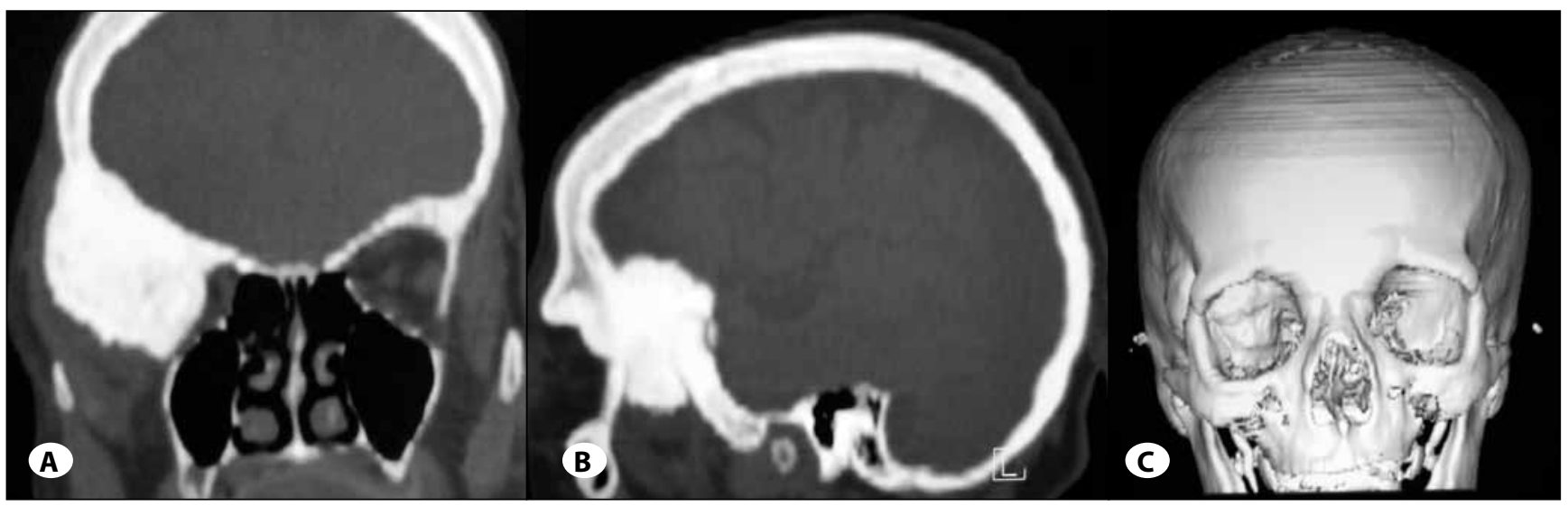

Figure 1: A) Coronal CT shows enlarging mass in right orbit. B) Sagittal CT shows expansive lesion of sphenoid bone. C) Threedimensional CT image of the cranium.

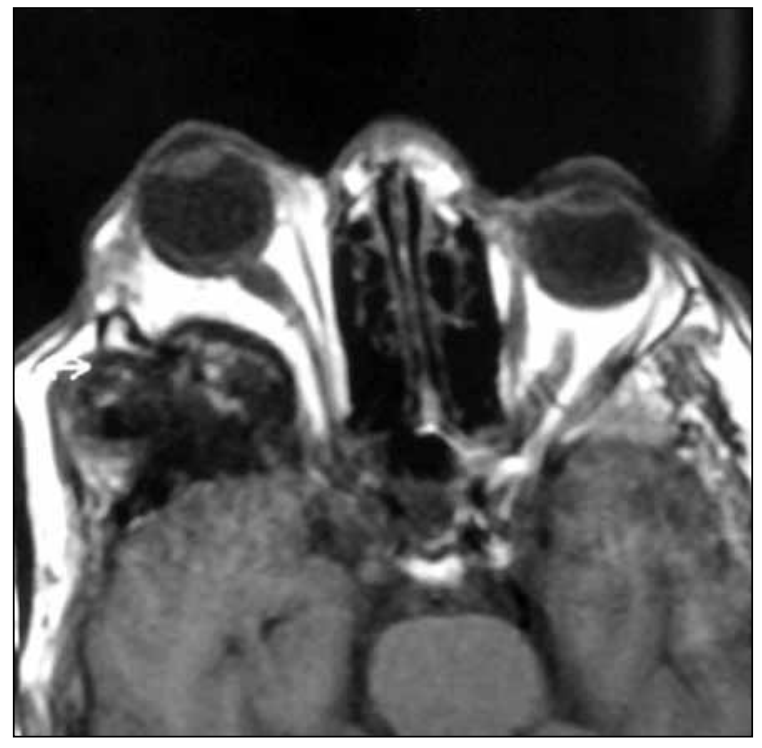

Figure 2: Axial MR imaging shows anteriorly deplacing of right globe and indentation of optic nerve.

of the patient. A right orbitozygomatic incision was performed and a biopsy was taken from the intraorbital mass. Histopathological diagnosis was a mature type osteoma (Figure 3A, B). The diagnosis of a primary osteoma of the orbit originating from the sphenoid bone was made. This time, an attempt to extirpate the tumor by craniotomy was not performed because of the cardio-pulmonary instability of the patient.

The patient had been prescribed nonsteroid analgesics and used them for 20 years, and her pain had become unresponsive to these drugs. Gabapentin 3x400mg was started, and after six days was increased to $3 \times 800 \mathrm{mg}$. Amitryptilline was given at a dose of $2 \times 10 \mathrm{mg}$. Her pain was significantly decreased.

\section{DISCUSSION}

Osteomas are predominantly located in the skull, paranasal sinuses, the jaws, and the calvaria. They are the most frequent benign tumor of the paranasal sinuses. Osteomas
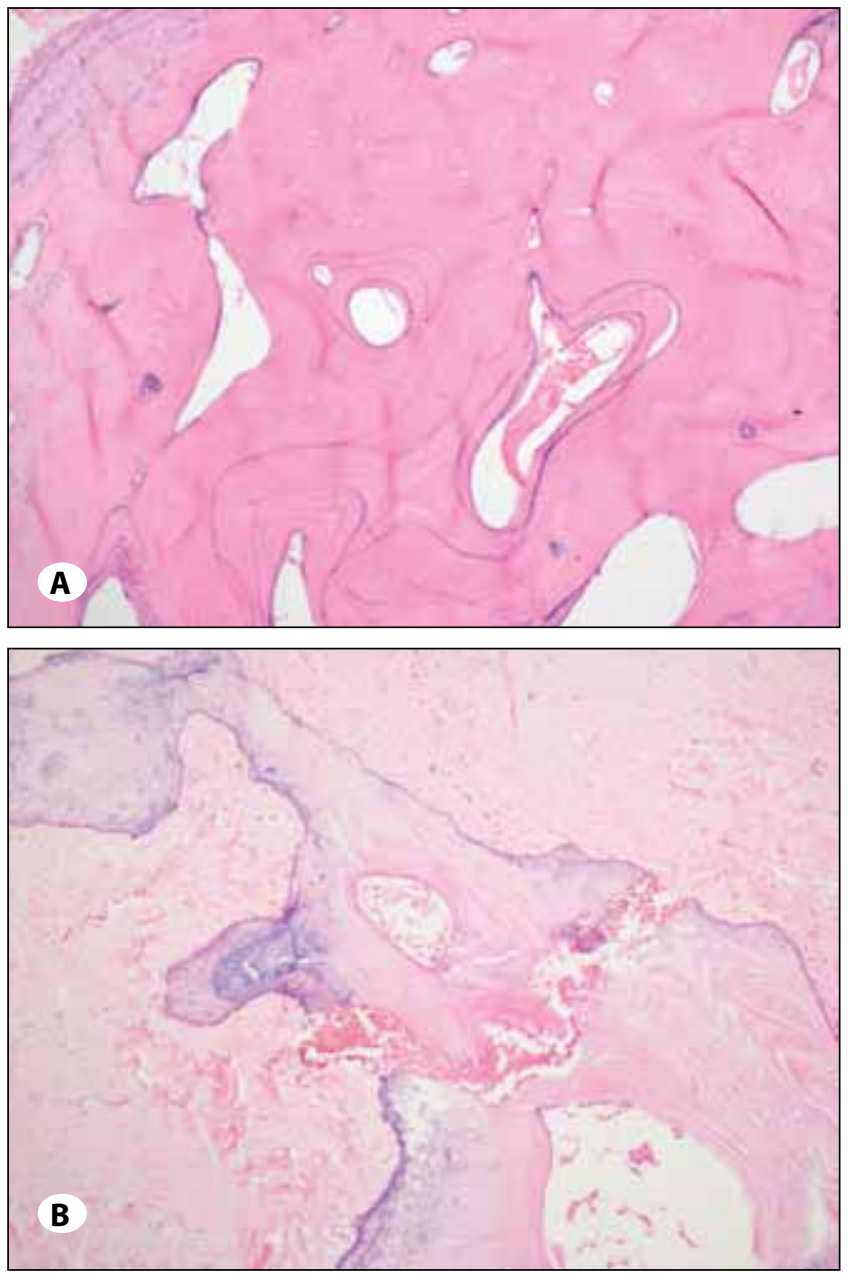

Figure 3: A) The mature and cortical type haversian bone tissue. (H\&Ex100). B) Immature bone feature in fibrous tissue (H\&Ex100).

of the paranasal sinuses are benign slow growing tumours, which usually become symptomatic after attaining a large dimension. The commonest site is the frontal sinus, followed by the ethmoid, maxillary and sphenoid sinus in that order (2).

Primary tumors of the orbital bones constitute $0.6 \%$ to 
$2 \%$ of all orbital tumors $(18,5)$. Mchugh et al. reported a clinicopathologic study of 45 surgically treated cases; the frontal sinus was the most common location (62\%) followed by the ethmoid and maxillary sinuses. In this series, 12 tumors (27\%) involved the orbita and only two of them arose primarily from the orbit $(0.9 \%)(12)$.

Sen analyzed 276 cases of orbital tumours over a period of 20 years did not find any case of primary osteoma (19). It is understood that in most caes of orbital osteoma, the cavity is secondarily affected due to ingrowth of an osteoma arising in adjacent structures, predominantly from the paranasal sinuses (10). Alper et al reported a case of an orbital osteoma that mainly originated from the medial orbital wall (1).

Ozdemir et al reported an incidentally found case of sphenoid sinus osteoma while they were investigating for otitis media. The tumor was located in the sphenoid sinus, there was no spread to orbit and the patient was asymptomatic. They operated using the transnasal endoscopic approach (16).

Primary osteoma of the orbit is not a common tumor $(10,17)$ However, osteoma of the orbit originating from the sphenoid bone is very rare. The three reported cases in the literature review, belonged to Thakur and Nema, Kleifeld and Ishikawa et al.

The first case was an osteoma of the lesser wing of the sphenoid (20). In the second case, CT revealed a spaceoccupying lesion originating from the orbital wing portion of the sphenoid bone and extending into the orbital roof of the frontal bone (14). The third case was an osteoma protruding into the pterygomandibular space from the lateral pterygoid plate of the sphenoid bone (11).

Our case was suggested to be a primary orbital osteoma. In addition, there was a mass at the posterosuperolateral wall of the orbit, which originated from the greater wing of the sphenoid bone, lobulated, and expanded to the sphenoid bone, filling $2 / 3$ of the orbital cavity.

Plain radiography is the basis of the diagnosis of osteoma (9). However, osteomas are best visualized with CT. Computed tomography is very important in the evaluation of bone extension of the tumor and also the site of origin (paranasal sinuses, orbital roof, ethmoid and sphenoid bone) may be often defined on the coronal scans (8).

Radiologically, osteomas manifest with well-delineated homogeneous radiodensity on plain film and CTs. On plain skull films, osteomas are identified as well-delineated, dense lesions adjacent to a paranasal sinus. The differential diagnosis of these lesions should include endochondroma, osteogenesis imperfecta, bone infarction, fibrous dysplasia, low-grade osteogenic sarcoma, ossifying fibroma and in unusual cases calcified meningioma (13). Osteomas often appear as a coincidental finding on X-ray in patients having radiographs for same other reasons. Tomographic evaluation is the mainstay for surgical access and its subsequent follow up (2).
In our case, plain x-ray showed a well-delineated right hyperdense intraorbital mass lesion. On cranial and orbital computerized tomographic scans, the lesion was seen as arising from posterolateral wall of the great wing of the sphenoid bone with a lobulated contour. It caused bony expansion in the sphenoid bone, and indentation on the lateral rectus muscle and optic nerve displacing the globe anteriorly (Figures $1 \mathrm{~A}-\mathrm{C}, 2$ ).

Histologically, osteomas may have osteoblastoma-like areas and distinguishing it from true osteoblastoma can be challenging. Some believe osteomas with osteoblastomalike features behave more aggressively. (12) These tumors are composed of irregular bony trabeculae and fibrovascular tissue. Traditionally the osteomas are divided into three types based on histopathologic appearance: eburnated (ivory), fibrous, and mature. The eburnated osteoma is primarily composed of thick bony trabeculae with little fibrous tissue. The fibrous type contains highly vascularized fibroadipose tissue between the bone elements, which may lead to a misdiagnosis of ossifying fibroma or osteogenic sarcoma (13).

In the histopathological specimens of our case the mature and cortical type haversian bone fragments were observed extensively in the sections. Rarely the presence of immature bone tissue was seen in some part of fibrous tissue. The interosseous space containing adipose tissue and blood vessels was also noted (Figure 3A, B). According to this microscopic findings, histopathologically, our case was diagnosed as mature type osteoma.

The differentiation of primary and secondary orbital osteoma is prudent in terms of surgical treatment planning and outcome assessment (10). Only patients with symptomatic osteomas should be treated when the osteomas are located anteriorly and simple excision will affect a cure, since recurrences are rare. However, when paranasal sinus osteomas or primary osteoma of the orbita invade the orbit posteriorly, particularly with optic canal involvement, the surgery is complex and should be performed by a craniofacial surgical team (13).

Our patient had right frontal pain which was radiating to the maxillary and mandibular areas and extending hemicranially to the back of the head was accepted as atypical cranial neuralgia. The intraorbital mass narrowing the superior and inferior orbital fissures and compressing neighboring vascular and neural structures could have caused the pain. Since it was unresponsive to ordinary analgesics, gabapentin and amitryptilline were started, which provided immediate effect.

\section{REFERENCES}

1. Alper M, Gurler T, Totan S, Bilkay U, Songur E, Mutluer S: Intraorbital osteoma and surgical strategy. J Craniofac Surg 9: 464-467,1998

2. Sinha A, Jha D, Deka RC: Osteoma of the paranasal sinuses. Indian Journal of Otolaryngology and Head-Neck Surgery 55:166-169, 2003 
3. Becelli R, Santamaria S, Saltarel A, Carboni A, lannetti G: Endo-orbital Osteoma: Two cases reports. J Craniofac Surg 13: 493-496-2002

4. Cherkaoui A, Oudidi A, El alami N: Orbital osteoma of Ethmoidal origin. Internal Journal of Otorhinolaryngology 10 : 2, 2009

5. Civit T, Freppel S, Baylac F: Primary bone tumors of the Orbit. Neurochirurgie 56:165-173, 2010

6. Duterme JP, Duchateam JP, Vanderkelen B: Frontal sinusitis, palpebral abscess and exophthalmia due to osteoma. Acta Otorhinoloryngol Belg 45:315-318,1991

7. Gierek T, Markowski J, Majzel K, Zbrowska-Bielska D: Primary Orbital tumors treated surgically in ENT department of Silesian Medical Academy in Katowice. Otolaryngol Pol 53: 13-18,1999

8. Grayeli AB, Redondo A, Sterkers O: Anterior skull base osteoid osteoma: Case report. Br J Neurosurg 12:173-175,1998

9. Greenspan A:Benign bone-forming lesions: Osteoma, osteoid osteoma and osteoblastoma. Clinical, imaging, pathologic and differential considerations. Skeletal Radiol 22:485-500, 1993

10. Henderson JW: Orbital Tumors, In: Henderson JW (ed), Orbital Tumors Third ed, New York: Raven Press, 1994:161-164

11. Ishıkawa T, Yashima S, Hasan H, Shimosato T, Imada S: Osteoma of the lateral pterygoid Plate of the sphenoid bone. Int J Oral Maxillofac Surg $6: 786-789,1986$

12. McHugh JB, Mukherji SK, Lucas DR: Sino-orbital osteoma: A clinicopathologic study of 45 surgically treated cases with emphasis on tumors with osteoblatoma-like features. Archives of Pathology Laboratory Medicine 133:1587-1593, 2009
13. Karcıoglu ZA: Orbital Tumors: Diagnosis and treatment: Fibroosseos and cartilaginous tumors and tumor like conditions, In: Karcioglu ZA (ed), Orbital Tumours: Berlin: Springer, 2005:174-186

14. Kleifeld O: Computer tomography in unilateral exophthalmos caused by an osteomas of the orbital wall (Author's transl). Klin Monbl Augenheilkd 176:447-449,1980

15. Livaoglu M, Cakır E, Karacal N: Large orbital Osteoma arising from orbital roof: Excision through an upper Blepharo-plasty incision. Orbit 28:200-202, 2009

16. Ozdemir O, Calısaneller T, Kıyıcı H, Altınors N: Sphenoid sinus Osteoma. Report of a case. Turkish Neurosurgery 16:85-88, 2006

17. Radtke J, Machtens E: Severe osteoma development in the base skull. Dtsch Z. Mund Kiefer Gesichtschir 10:180-183, 1986

18. Selva D, White VA, O'Connell JX, Rootman J: Primary bone tumors of the orbit. Survey of Ophthalmology 49:328-342, 2004

19. Sen DK: Aetiological pattern of orbital tumours in India and their clinical presentations: A 20-year retrospective study. Orbit 9:299-302,1990

20. Thakur V, Nema HV: Osteoma of the lesser wing of the sphenoid. Eye Ear Nose Throat Mon 48:619-621,1969 